\title{
Municipal Solid Waste Management in South Assam: Current trend, Scope and challenges for growing Mini City Silchar, Assam, India
}

\author{
Moharana Choudhury*1, Joystu Dutta ${ }^{2}$ and Hari Shankar Prasad Tonde ${ }^{3}$ \\ *1Department of Environmental Science, Tezpur University (Assam) - India \\ ${ }^{2}$ Department of Environmental Science, Sarguja University, Ambikapur (Chhattisgarh) - India \\ ${ }^{3}$ Department of Computer Science, Sarguja University, Ambikapur (Chhattisgarh) - India \\ *Correspondence:joystu.dutta@gmail.com
}

\begin{abstract}
Municipal solid waste management is a humongous problem for majority of developing countries across the world. Spontaneous commercial, residential and infrastructural development due to population explosion has caused negative impacts on the inhabiting environment. Unplanned townscapes and lack of proper scientific and technical expertise in MSW management has complicated the problems further. In the current paper, we tried to investigate the root cause of such common urban problems considering Silchar Mini City as one of the fastest growing population hubs in south Assam. The population of the city is nearly two lakhs according to the census of 2011, thus generating around 85 MT (metric ton) of Municipal waste every day which consists of house hold waste (50\%), market waste (39\%), street waste (6\%), and other commercial wastes including the E-waste in total (5\%). The per capita rate of waste generation is $240-250$ gram per day on average. The current study assesses the present trends, scopes and the way forward in sustainable municipal solid waste management in coming times in Silchar City. Such studies should also be undertaken for rapidly developing cities across India to generate a database of city wise waste generation across the country. This would also provide a roadmap for the techniques adopted in sustainable management of the waste.
\end{abstract}

Keywords: Waste management, municipal solid waste, population hub, Silchar town

\section{Introduction}

Municipal Solid Waste Management is one of the major environmental problems in Indian cities $^{[1]}$. Urban waste management is a key environmental issue related directly with human health concerns ${ }^{[2]}$. Municipal solid waste disposal has been a chronic problem, particularly in areas with high population density, high production of refuse, and scarcity of land adequate for landfills with scientific measures ${ }^{[2]}$. Our environment is facing a potential threat from unsustainable waste disposal system which almost in all urban cities, consequence of our lifestyle, waste does not cease growing in quantity, in complexity even in harmfulness. Urban solid wastes are not an ordinary product, and some wastes can also be turned into useful resources. Moreover some by-products and discarded items are not exactly wastes but as secondary resource product; they are collected for reuse as recovered products or for recycling as recovered materials ${ }^{[3]}$. Unplanned solid waste management system as in open dumping of wastes which may results contamination of ground water system as well as surface water sources4. There has been a significant increase in solid waste generation in India over the years from
100 gm per person per day in small towns to 500 grams per persons per day in large towns at presently most of the municipal solid waste in India is being disposed unscientifically ${ }^{[5]}$.Generally municipal solid waste is collected and deposited in sanitary landfill, such unscientific disposal attract birds, rodents and fleas to the waste dumping site and create unhygienic conditions ${ }^{[6]}$. The degradation of the solid waste results in the emission of carbon dioxide, methane and other trace gases ${ }^{[7,8]}$. In recent study on solid waste dumping ground that for waste disposal of Silchar town and found that dumping ground is unscientific which resulting contamination of water bodies and burning of wastes at dumping area directly effecting surrounding in habited area badly ${ }^{[9]}$.The main intension of this study is to find out the municipal solid waste management scenario and its environmental aspects.

Materials and Methods: To access out the existing situation of urban solid waste management system for any urban area is very important from an environmental aspect ${ }^{[10,11]}$. It has already proved by several researches so far, that the most environmental problem resulting from poor waste 
management systems which because of greenhouse gas emissions, water pollution, soil pollution and resources depletion etc thus waste management is very important for sustainable development ${ }^{[12]}$. The present study comprises of both qualitative and quantitative analysis of waste that generated by Silchar mini city which include two processes, collection of entire waste generated by the city and its disposal process that guided by MSW, GOI rule ${ }^{[13]}$. The guidelines and proper methodology are as shown in figure (1). The rules are given below.

- Municipal solid waste is collected from different places and delivered to fixed storage bins made of concrete blocks. Biomedical wastes are disposed of as per the procedure of the bio medical rules $1998^{[14]}$.

- Segregation of solid waste

- Storage of solid waste in the storage bin and at hygiene places.

- Transportation process in closed vehicle.

- Processing and disposal of solid waste by the process of land filling at dumping site.

Primary data collected from Silchar Municipal Board ${ }^{15}$ to assess the present urban solid waste management scenario of the city. The data were collected in and around different part of the city along with sources of waste generation and assessment of public consciousness regarding the urban solid waste, some photographs also taken from the different part of city at the time of survey. Authors did a ground field survey to understand the complete collection and disposal process so solid waste management process ${ }^{[14]}$. The main intention of this present study was to get a glimpse of the current trend of solid waste management trend of the city. Here some steps that considered for this study and analysis done based on these points as below.

1) Waste collection process

2) Record keeping details

3) Transportation process

4)Monitoring process

5)Staff involvement in collection, and deposal process

6) Technical equipments and management process

7) Site observation

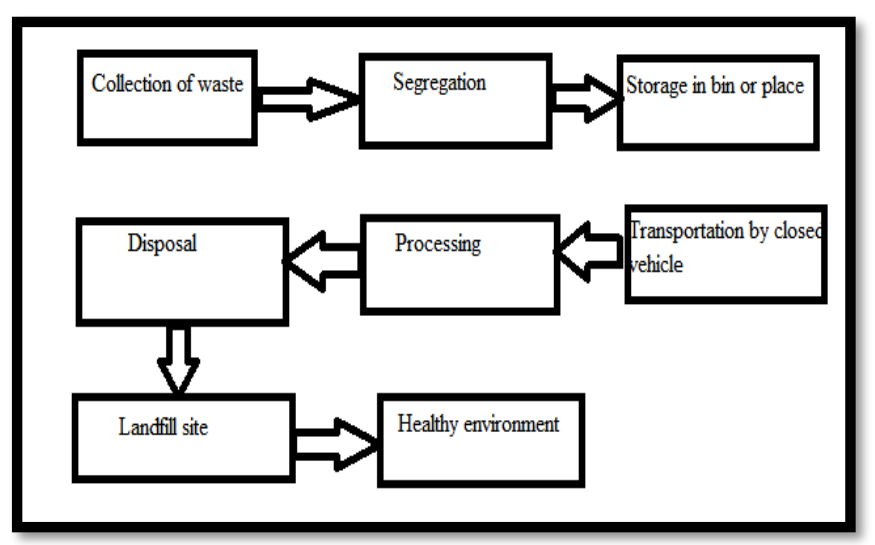

Fig. 1: Methodology for management of municipal solid waste by GOI)

\section{About Study Site:}

Silchar $\left(24^{\circ} 49^{\prime} 47^{\prime \prime} \mathrm{N} 92^{\circ} 46^{\prime} 11^{\prime \prime E}\right)$ is located at the southern part of Assam situated on the Barak River. It is a trade and processing centre for tea, rice and other agricultural products. There is limited industry, principally papermaking and few small scale industries. The town has an airport and lies on both a rail head and national highways connecting to Guwahati, Assam. National Highways (NH) connecting Agartala, Tripura, Imphal, Manipur and Aizawl in Mizoram state respectively and the town naturally plays a vital role so far supply of essential commodities etc to those states is concerned. It has an average elevation of 22 meter ( 72 feet). Silchar town is fastest growing town in state of Assam, the Silchar town is very old town it has a proud heritage of the public who inherit its culture and character. Silchar being the heart for educational centre and well recognised for National level Institutions, Universities as NIT Silchar, Assam Central University, Silchar Medical College and many colleges, schools and institutions ${ }^{[15]}$. It is having population of 178,865 according to the 2011 census along with floating population, government employees, for business and education. As Silchar is centre for administrative point of view thus here all government offices situated. The literacy of Silchar town as 2011 census was 91.7, higher than the national literacy rate. The climate of Silchar is tropical in nature, humid and hot summer. Generally Silchar receives heavy rainfall during rainy seasons with thunderstorms and cold winter ${ }^{[16]}$.

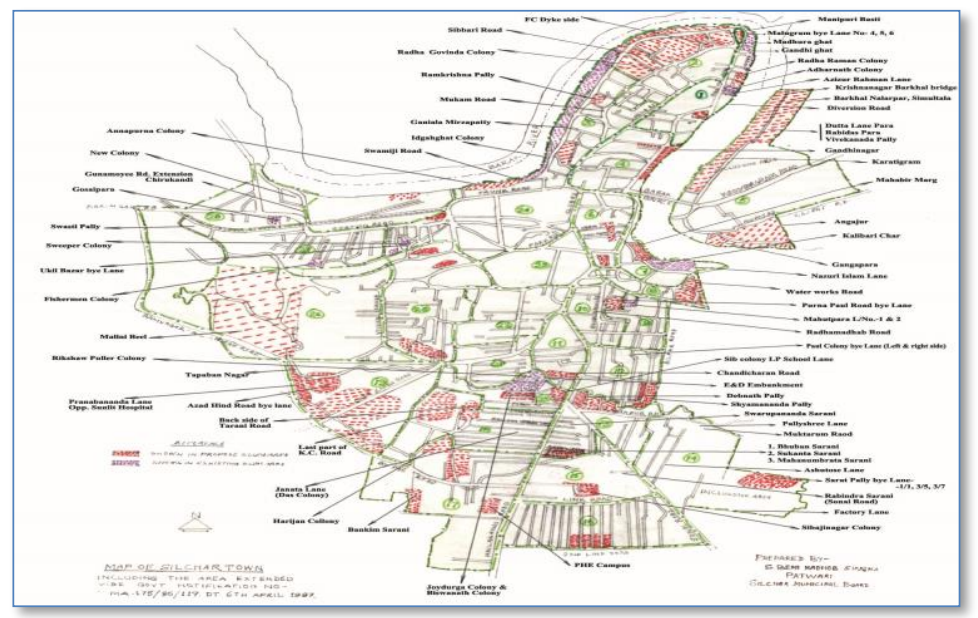

A brief history of Silchar Municipality:

As the British settled town in the area, the head quarter of the district began to take an urban look, the need for proper administering of the town from the point of health, sanitation, road, drinking water etc. was felt accordingly, Silchar Station Committee (town committee) was constituted in the year 
1882. After 32 years of its function as such, it became Municipal Board in the year 1913. During the period (1882 1913), deputy Commissioner of the district was the Chairman of the station committee by virtue of his office. First election was held in the year 1913 on the principle of local selfgovernment and the elected Chairman (Indian) took over the charge of Municipality.

\section{Result and Discussion:}

Data are collected from Silchar Municipal Board (SMB) and other secondary data collected from filed survey along with public questioner, these data analysed according to MSW management and handling rule 2000, to access the current trend, Scope and challenges of SMB to management of municipal solid waste with respect of environmental aspect.

Table 1

\begin{tabular}{|c|c|c|c|}
\hline $\begin{array}{c}\text { Ward } \\
\text { No }\end{array}$ & $\begin{array}{l}\text { Population as } \\
\text { per } 2001\end{array}$ & $\begin{array}{l}\text { Population } \\
\text { as per } 2011\end{array}$ & $\begin{array}{c}\text { Area } \\
(\mathrm{Sq} . \mathrm{Km} .)\end{array}$ \\
\hline 1 & 5271 & 6057 & 0.3748 \\
\hline 2 & 8398 & 7229 & 0.6216 \\
\hline 3 & 6429 & 10933 & 0.5893 \\
\hline 4 & 4014 & 4084 & 0.3841 \\
\hline 5 & 10298 & 18493 & 1.3398 \\
\hline 6 & 1831 & 1912 & 0.3618 \\
\hline 7 & 6407 & 6866 & 0.2959 \\
\hline 8 & 1596 & 1803 & 0.2984 \\
\hline 9 & 4728 & 4397 & 0.2324 \\
\hline 10 & 3038 & 3927 & 0.2817 \\
\hline 11 & 3416 & 3475 & 0.2884 \\
\hline 12 & 4557 & 5281 & 0.2969 \\
\hline 13 & 4420 & 4462 & 0.3721 \\
\hline 14 & 6038 & 8175 & 0.9334 \\
\hline 15 & 3324 & 2591 & 0.1855 \\
\hline 16 & 4755 & 6256 & 0.8765 \\
\hline 17 & 4928 & 6778 & 0.8926 \\
\hline 18 & 6031 & 7297 & 0.7104 \\
\hline 19 & 5406 & 7268 & 0.2897 \\
\hline 20 & 4236 & 4466 & 0.1964 \\
\hline 21 & 3867 & 3833 & 0.2713 \\
\hline 22 & 4302 & 4913 & 0.3853 \\
\hline 23 & 2638 & 2702 & 0.3853 \\
\hline 24 & 5745 & 9508 & 0.8975 \\
\hline 25 & 6117 & 7306 & 0.8844 \\
\hline 26 & 5183 & 7969 & 1.5068 \\
\hline 27 & 6740 & 7708 & 0.6874 \\
\hline 28 & 8486 & 7141 & 0.9077 \\
\hline Total & $1,42,199$ & 172830 & $\begin{array}{c}15.7466 \\
\text { (Present) }\end{array}$ \\
\hline
\end{tabular}

Table (1) Census data as per 2001 and 2011, Ward wise population and area (Silchar Mini City)

As there is rapid population growth in the region which is resulting continuous increase in waste generation. A present in total amount of waste is around 85 MT (metric ton) per day in the city. There are at present 28 wards in the Silchar Mini City and out off all these wards the ward no 5 and 3 consisting more no population compare to others which are 10933 and 18493 respectively as per 2001 as well as 2011 census report that shown in table (1) thus, generation of waste is also more from these wards. The wastes consists of house hold, commercial, construction debris, electronic wastes, biomedical waste etc. Here the qualitative and quantitative composition of municipal waste generation details Silchar Mini City is given below.

Solid Waste of Silchar includes garbage (food waste), rubbish (paper, plastic, wood, metal, throw-away containers, glass etc.) demolition products (bricks, masonry and pipes), sewage treatment residues, dead animals manure and other discarded materials. So, Municipal Solid Waste (MSW) is a heterogeneous mixture of rags, stones, soils, besides food and vegetable waste from kitchen and market. Owing to rapid urbanization and migration of in rural people into urban areas as well as change in consumption pattern, urban population has increased from $23 \%$ to $32 \%$ during 1991-2001 in India ${ }^{16}$, same trend is also observed in Silchar Mini City also as from 1991 to 2011 the population has increased significantly as $23.60 \%$ and $21.54 \%$ growth observed from 2001 to $2011^{[17]}$ which shown in table 2 and figure (3) graph below. Main sources of Solid waste in Silchar Mini City, generally four (4) types as 1) Household of Domestic Waste 2) Market Waste 3) Street Waste 4) Commercial establishment waste. Other wastes are also there but they are not at all acute in nature.

Household or Domestic waste: Household waste consists of ash, garbage and rubbish etc. Ash is the residue from fire used for working \& heating of products. Rubbish comprises of papers, clothing, and remains of wood product, metal, glass, dust and dirt.

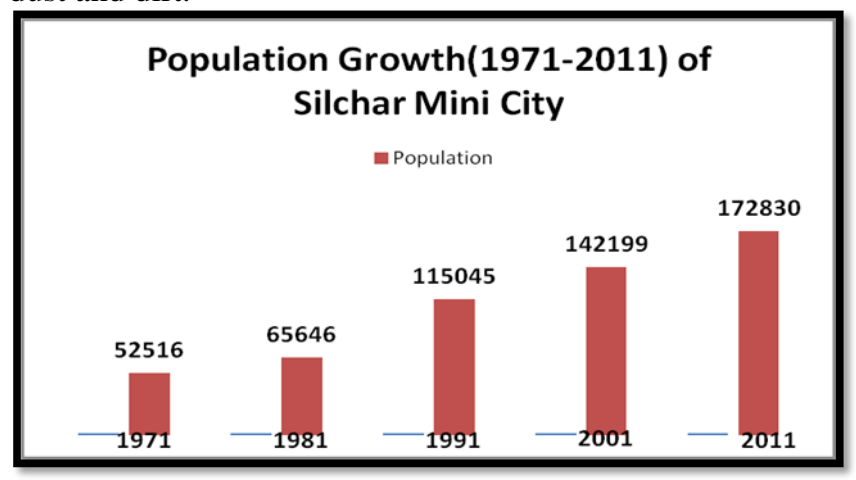

Garbage is generally waste matter arising from the preparation, cooking and consumption of food products which consists of waste food, vegetable peelings and other organic matter etc. Estimation was based on survey. The estimation is around $250 \mathrm{gms} /$ per day (per capita) that considered for household waste generation for Silchar Mini 
City, which calculated as sum total of 40.96 MT/Day waste as household waste according to 2011 census report shown in the table (3) below where $3 \%$ of non-biodegradable and rest bio-degradable wastes as $97 \%$.Proper handling of house hold waste is also important because the wastes can cause infraction to human health because of decomposition ${ }^{18}$.

\begin{tabular}{lllll}
\hline Year & $\begin{array}{c}\text { Total } \\
\text { Population }\end{array}$ & $\begin{array}{c}\text { Total Area } \\
\text { (Sq. Km.) }\end{array}$ & $\begin{array}{l}\text { Increase in } \\
\text { Population }\end{array}$ & $\begin{array}{l}\text { Increase } \\
\text { In \% }\end{array}$ \\
\hline 1971 & 52,516 & 10.00 & - & \\
1981 & 65,646 & 13.25 & $\mathbf{1 3 , 1 2 9}$ & $\mathbf{2 5 \%}$ \\
1991 & $1,15,045$ & 15.25 & $\mathbf{4 9 , 4 0 0}$ & $\mathbf{7 5 . 2 5 \%}$ \\
2001 & $1,42,199$ & 15.75 & $\mathbf{2 7 , 1 5 4}$ & $\mathbf{2 3 . 6 0 \%}$ \\
2011 & $1,72,830$ & 15.75 & $\mathbf{3 0 , 6 3 1}$ & $\mathbf{2 1 . 5 4 \%}$ \\
\hline
\end{tabular}

Table (2) and figure (3): Year wise Population growth of Silchar from (1971-2011)

\begin{tabular}{cc}
\hline Household Waste & $43.20 \mathrm{MT} / \mathrm{Day}$ \\
Market Waste & $32.00 \mathrm{MT} / \mathrm{Day}$ \\
Street Waste & $5.00 \mathrm{MT} / \mathrm{Day}$ \\
Waste & $4.00 \mathrm{MT} / \mathrm{Day}$ \\
Other Commercial Establishment & $\mathbf{8 4 . 2 M T / D a y}$ \\
Total Solid Waste & (Approx) \\
\hline
\end{tabular}

Table (3): Estimated waste generation of Silchar Mini City

Market waste: Market Wastes are the refuse that is collected from market. It contains large proportion of putrid vegetables, animal matter, and plastic products. Estimation done on basis of observation, interview and on the quantity that transported for dumping. During the present study it is noticed and estimated that the amount of non-biodegradable waste are only $5 \%$ of total market waste.

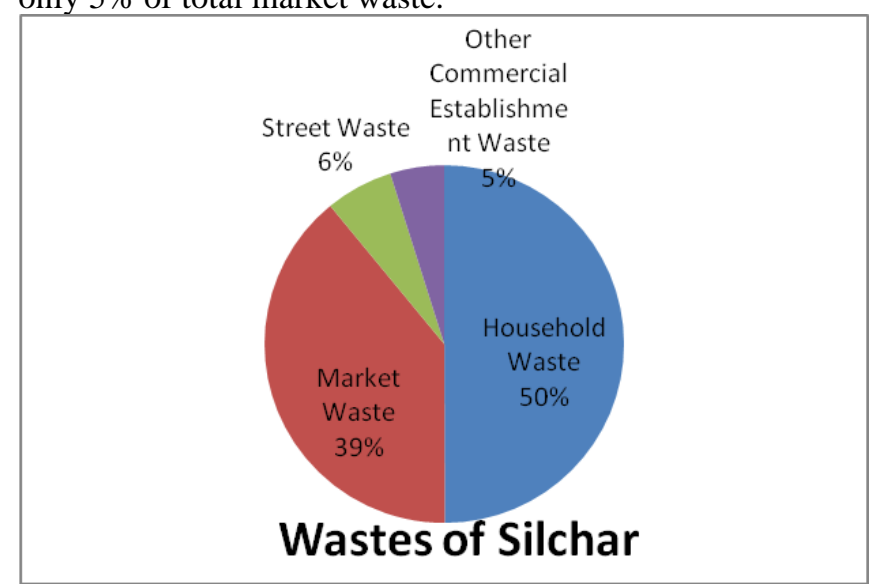

Figure (4): Wastes generation sources of Silchar Mini City

Street waste: It consists of leaves, straw, paper, animal droppings and litter of all kinds and large quantities of nuisance like plastics, polythene etc. Non-biodegradable waste was nearly $4 \%$. Other commercial establishment waste: Generally arises from commercial establishment like Hotels,
Restaurants, and Stationary Shops of residential as well commercial area Estimation was carried out both on the basis of interview and observation and here Non- biodegradable waste estimated around 3\% of total.

Household hazardous waste: These comprises of household items such as paints, cleaners, oils, batteries, pesticides, Toxic, Corrosive, Flammable or Poisonous products that might contain hazardous materials thus these products are called as Household Hazardous Waste. These wastes are mostly non-biodegradable substances and estimated around $2 \%$ of total waste.

Table (4a): Showing details of manpower involved in waste management (Source: SMB)

Table (4b): Showing details of technical equipments and manpower involved in waste management Source: SMB

It is also observed that there is no practice of segregation of waste as "Bio-degradable" and "Non biodegradable" except few households or waste collection system at Silchar Mini

\begin{tabular}{lll}
\hline SL. NO. & \multicolumn{1}{c}{ DESIGNATION } & NUMBER \\
\hline 1. & Municipal Inspector & 1 \\
2. & Deputy Municipal Inspector & 1 \\
3. & Supervisors & 6 \\
4. & Driver & 9 \\
5. & Street Sweeper & 30 \\
6. & Sanitary Worker (Labourers ) & 59 \\
& Total & $\mathbf{1 9 0}$ \\
\hline
\end{tabular}

City. In the estimation it was noticed that percentage of Biodegradable waste of the Silchar Mini city around $97 \%$ and

\begin{tabular}{llll}
\hline $\begin{array}{c}\text { S1. } \\
\text { No. }\end{array}$ & $\begin{array}{c}\text { Type of } \\
\text { Vehicle }\end{array}$ & $\begin{array}{c}\text { In } \\
\text { Position }\end{array}$ & Functioning \\
\hline 1. & Truck & 02 & 02 \\
2. & Tractor & 05 & 03 \\
3. & Tipper & 02 & 02 \\
4. & Excavator & 01 & 01 \\
& Total & 10 & 8 \\
\hline
\end{tabular}

Non biodegradable waste is around $3 \%$ of total waste generated.

Primary Collection System: It has been observed that there is no primary collection system of Municipal waste at Silchar Mini City. As there is no proper storage bins or centres, the waste is thrown on the streets, drains and on the open spaces. Some storage bins placed in different part of Silchar Mini city but, they are not sufficient and unscientific. There is no provision to collect the waste from small roads and lanes. It is also observed that wastes are scattered here and there on the streets and markets areas. It is very common to find large heaps of garbage in unorganized manner on the streets and market area which are creating flies, bad smells, mud and finally may create serious environmental and health problems as waste contains various toxic substances.

Transportation system: 
Transportation system for municipal waste management is generally done through uncovered trucks, tractors, trailers which are operated by Silchar Municipality there in total 8 numbers of trucks, tractors and tipper presently working which shown in table (4). The process of collection of waste is generally done twice in a week. It has also been observed that, the loading and unloading of wastes from trucks are done manually i.e. by employs of SMB which is around 50 to 55 numbers of person involved in the process which leads by six supervisors and one each deputy Municipal Inspector and Inspector respectively shown in table (4). It is also noticed that around $40 \%$ of total wastes are collected and transported for final disposal from the street and market area.

Street sweeping: It is also observed that Street sweeping is not carried out regularly except in some main roads of the Silchar Mini City as there are around 30 numbers of sweepers associated with SMB for sweeping and other work but, this number is insufficient for vast area of Silchar Mini City.

Waste Disposal: Municipal Dumping site of SMB is generally known as Kuarpar which is the only dumping site for Silchar Mini City and is located at distance around $2.0 \mathrm{~km}$ away from the Municipal boundary of Silchar City. This area lies on main road called as Silchar-Hailakandi road which is connecting road link of some very important institutions as Silchar Medical College, Silchar Polytechnique, NIT Silchar, Assam Central University and Numbers of nursing homes etc. The dumping ground is situated around 400-500 meter from the main road i.e. Silchar-Hailakandi road. During the present study it is observed that the dumping ground is Uncontrolled, unscientific and non-segregated in respect of Bio-degradable and Non Bio-degradable waste. The present dumping site is surrounded by Meherpur and Ghungoor Gaon Panchyate area. The present dumping site is effecting directly areas as new development road, Naga Punji, Kuarpar, Birbal Bazar, Anath Camp, Migrant Camp and other organisational body as Silchar Polytechnique, LP School, Union floor Mill, nightingale Hospital, Medinova Nursing Home, the Sun city Building project etc. The total habitation around the dumping site is nearly about $10,000-12,000$ who are directly suffering the adverse effect of this dumping site. Municipal Solid Waste (MSW) is generally a heterogeneous mixture of rags, stones, soils, besides food and vegetable waste from kitchen and market. Solid waste if allowed to accumulate is a health hazard because as it decomposes and favours fly breeding, attracts rodents and vermin. Pathogen which may be present in the solid waste may be conveyed back to man's food through flies and dust. So there is a high possibility of water and soil pollution. Heaps of refuse present an unsightly appearance and nuisances from bad odours. There is correlation between improper disposal of solid waste and vector borne diseases ${ }^{[19,24,25]}$.

\section{Conclusion:}

Solid waste is now becoming a major issue for any administration especially in growing cities such as Silchar of Assam, India. Population explosion, rapid urbanisation, unscientific town planning and lack of public awareness is adding to the problem. Silchar Mini City is at a rapid development phase as the second largest city in state of Assam. The city is facing crisis as far as management of solid municipal waste is concerned with production of around $85 \mathrm{MT}$ of waste per day. Disposal of waste is the major problem as the open dumping ground is affecting the people and environment around the site. Immediate measures for proper scientific disposal of waste either by adopting a composting method or waste recycling is needed. Some advanced technical measures to tackle sustainable waste management is further required. There is a good scope of Biogas production from wastes of Silchar city because in average almost $97 \%$ waste is bio-degradable which is very suitable for such project ${ }^{[17,18,19]}$. Segregation of solid and liquid wastes is also a very important issue for Silchar City. Utmost care during the collection period might led to fruitful implications in future. The local administration and people should develop the initiative for sustainable waste management. Citizen involvement in the process is the need of the hour. As per a study it was found that citizen are willing to pay for better waste management for Silchar City ${ }^{[20,21,22]}$ thus a safe and better environment can be achieved for every citizen ${ }^{[23]}$.

Acknowledgement: The authors are thankful to the Silchar Municipal Board (SMB) Silchar, India for their cooperation during the study. Authors are also thankful to citizens of Silchar Mini City, members of organisation Voice of Environment for their technical support and cooperation during the survey and study.

\section{Reference:}

[1]. Sharholy, M., Ahmad, K., Mahmood, G., Trivedi, R. C. (2008). Municipal Solid Waste Management in Indian cities: A review. Waste Management (28) pp 459-467.

[2]. Alen AR, Dilon AM, O’Brien M., 1997. Approaches to landfill site selection in Ireland. Engineering Geology and the Environment. Balkema, Roterdam pp $1569-1574$.

[3]. Sadek, S. and El-Fadel, M. (2000). The Normandy landfill: A Case Study in solid waste management. Journal of Natural Resources and Life Sciences Education, 29: 155-161.

[4]. Bertolini, G. Extra- and intra-European Union exchanges of recovered materials and products. Resources Policy, vol. 29, 2003, pp. 153-164.

[5]. Rajkumar, N., Subramani, T. and Elango, L. (2010). Groundwater contamination due to municipal solid 
waste disposal - A GIS based study in erode city. International Journal of Environmental Sciences, 1: 39-55.

[6]. Akolkar.AB., 2005. Status of Solid Waste Management in India, Implementation Status of Municipal Solid Wastes, Management and Handling Rules 2000, Central Pollution Control Board, New Delhi.

[7]. Suchitra M, 2007. Outside: Burnt or buried, garbage needs land. Down to Earth, 15 March, pp. 22-24.

[8]. MeBean E A, Rovers F A and Farquhar G J, Solid Waste Landfil Engineering and Design, Prentice Hal, NJ, 1995, p. 380.

[9]. Amar M Dhere, Chandrasekhar B Pawar, Pratapsingh B Pardeshi and Dhanraj A

[10]. Patil, 2008. Municipal solid waste disposal in Pune city-An analysis of air and groundwater pollution Current science 95, 6,773-777.

[11]. Choudhury, M. (2014). Municipal Solid waste generated by Silchar town and its impact on surrounding area of dumping site at Meharpur, Silchar, International Journal of Environment and Natural Sciences 1(41-43)

[12]. Kamboj, N. and Choudhury, M. (2013) Impact of solid waste disposal on ground water quality near Gazipur dumping site, Delhi, India. 306 Journal of Applied and Natural Science 5 (2): 306-312

[13]. Den Boer J, den Boer E, Jager J (2007) LCA-IWM: a decision support tool for sustainability assessment of waste management systems. Waste Manag 27:1032-1045

[14]. Inazumi, S., Ohtsu, H., Shiotani, T., Katsumi, T. (2011) Environmental assessment and accounting for the waste disposal stream in Bangkok, Thailand. J Mater Cycles Waste Manag 13:139-149

[15]. Municipal solid waste (Handling and management) rule 2000. Ministry of Environment and forests, Gazette of India

[16]. Biomedical wastes (Handling and management) rule 1998. Ministry of Environment and forests, Gazette of India.

[17]. Data report of Silchar Municipal Board, Silchar Assam, India.

[18]. Report of the Steering Committee on Urban Development for Eleventh Five Year Plan (20072012) by Planning Commission Government Of India, New Delhi

[19]. Census report by Government of India, New Delhi

[20]. Lardinois I, van de Klundert A. Vol. 1. Amsterdam and Gouda: Tool, Transfer of Technology for Development and WASTE Consultants; 1994. Organic waste, urban solid-waste series.
[21]. George T, Theisen H, Vigil S. Engineering Principles and Management Issues. New York: McGraw-Hill; 1993. Integrated solid-waste management.

[22]. Roy, A. T. and Deb, U. (2013) Households Willingness to Pay for Improved Waste Management In Silchar Municipal Area: A Case Study In Cachar District. IOSR Journal of Humanities And Social Science Volume 6(5) PP2131

[23]. Karak, T., Bhagat, R. M., Bhattacharyya, P. (2012) Municipal solid waste generation, composition and management: The world scenario. Critical Rev Environ Sci Technol 42(15):1509-1630

[24]. Joseph, K. Electronic Waste Management in India issues and strategies.

[25]. Government of Assam, Environment and Forests Pollution Control Board. 